DOI: http://doi.org/10.21698/simi.2018.fp27

\title{
EXPLORING THE POSSIBILITIES OF AIR PURIFICATION IN URBAN ENVIRONMENTS USING GREEN ROOFING
}

Irina Tsvetanova, Ivanka Zhelev

Ruse University, Department Thermo engineering, Hydraulics, Ecology, 8 Studentska, 7017, Ruse, irinaic@abv.bg,vzh@abv.bg,Bulgaria

\begin{abstract}
According to European Commission studies, poor quality air causes the premature death of more people than the road accidents each year. Fine particulate matter (PM10) is mainly a result of human activities - transport, industry and domestic heating and causes respiratory problems, asthma, lung cancer and premature death. At present in Bulgaria, sources of pollution are mainly old cars and solid fuel stoves used for domestic heating. The environmental situation can be improved by building more green areas. In cities it is difficult to separate areas where green areas are to be built. This problem can be solved by using the roofs of buildings. Many plant species are resistant to pollutants and have the property of purifying the air from them. Properly designed roof gardens and the appropriate choice of plant species could significantly improve urban conditions.

The purpose of this article is to explore the possibilities for purification and improvement of air quality in urban zones using roofing landscaping. A study of literature on this problem has been made and presented in the paper. Also how to solve the problem with PM air pollution using green roofs in Bulgaria was commented. In the paper we estimate two simulations done by the software PLUME for annual average dust concentrations before and after construction of green roofs in the Industrial zone of the city of Ruse, Bulgaria. The maximum annual average concentration of dust after the building of green roofs is more than two times less than the one without green roofs.
\end{abstract}

Keywords: air pollution, dust retention, fine particulate matter (PM), green roofs

\section{Introduction}

Sprawl of cities, growth of population and traffic deepen, and complicate the problem of increasing air pollution in urban environments. Population growth and concentration in large cities leads to increased traffic, while construction and pollution at the same time reduce green areas. The combination of these factors leads to a worsening of the ecological situation. Deteriorated environmental conditions, high levels of air pollution cause serious damage to human health. The environmental situation can be improved by building green areas, thus reducing air pollution in the urban environment and creating a pleasant urban environment and better living conditions of the population. Landscaping of buildings has been a 


\section{INTERNATIONAL SYMPOSIUM "THE ENVIRONMENT AND THE INDUSTRY", SIMI 2018, PROCEEDINGS BOOK}

common building practice in advanced countries for several decades. Its popularity around the world has become even greater in recent years in connection with the concept of greening construction (Koleva 2011). In the cities it is difficult to separate spaces in which to build new green areas. The available green areas are not enough and they cannot cope with high levels of air pollution. Rooftop landscaping in many places in large cities can replace and complement traditional gardens and parks. In the large cities, it is very difficult to separate free terrains to build green areas, especially in the central areas. The reason for this is the lack of free terrains, as well as their high prices. In the cities there is often a lot of dense construction, crowding and intense trafficking. The combination of all these factors requires different solutions to the air pollution problem for the urban areas. One possible solution is the use of roofs for building of gardens. In today's urban environment, flat-roofed buildings are very well suited to building gardens. In this way, instead of a "forest" of concrete and gray and boring roofs people can enjoy beautiful views and lots of greenery (VEDAG GmbH 2007).

Garages, underground parking lots, public, commercial, warehouse, production etc. buildings can be used for the construction of green roofs. Another advantage of roofing landscaping is the improvement of thermal insulation during all seasons and improved energy efficiency, which, although indirectly contributes to the reduction of pollution. In this way, people can use less energy to heat or cool their homes, and this would reduce the electricity and heat generation needs, whose production also seriously pollutes the environment. In addition, green roofs help to restore the disrupted ecological balance in cities. Plants have a favourable role in lowering the maximum daily temperatures by several degrees in summer, increasing air humidity, enriching it with oxygen, accumulating toxic gases, retaining heavy metals, releasing substances that reduce disease-causing organisms (phytoncides). Enriching the air with oxygen is due to the ability of plants to absorb carbon dioxide from the air and release oxygen. As a result of the physiological and biochemical processes in the plants, the contaminated air is diluted with oxygen-enriched air, their ratio changes and the composition of the air as a whole is improved. This phenomenon, known as oxidation, contributes to the healing of the air (VEDAG GmbH 2007). What will be the degree of efficiency of roof gardens depends on their size, area and species composition, as well as the degree of pollution and the type of pollutants. Not all types of trees, shrubs and grasses digest carbon dioxide and emit oxygen at one and the same degree. For example studies have been carried out to prove that common spruce produces 4.5 times less oxygen than summer oak and the pyramidal poplar separates 7 times more oxygen than ordinary spruce (Koleva 2011, Doncheva-Boneva 1987). Overall, the study found that broad-leaved trees emit larger amounts of oxygen than coniferous trees (Koleva 2011). This does not give the benefits of deciduous species, because the climate and the fact that the deciduous species remain without leaves and do not photosynthesize during the autumn-winter period. Plants have good dusting properties: the leaves, branches and stems of the trees, hedges (which can be included in the roof gardening) and bushes are a good dust accumulator from the air. Many plant species are resistant to atmospheric 


\section{INTERNATIONAL SYMPOSIUM "THE ENVIRONMENT AND THE INDUSTRY", SIMI 2018, PROCEEDINGS BOOK}

pollutants and have the ability to purify the air from them. Properly designed roof gardens and the right choice of plant species, depending on climatic conditions and main pollutants, can significantly improve urban conditions. Roof gardens are beautiful and very suitable for increasing green areas in the urbanized environment without being linked to the demand for free space. For this purpose, free space can be used to increase green areas. This greatly reduces air pollution levels. Experience can be traced back to ancient times. The green roofs are one of the oldest models of roofs, traces of which are found even in stone-age dwelling. Information about roof gardens was discovered during the Babylonian Empire. The ancient Romans used their terraces and roofs to grow plants, and the roofs of the larger buildings were turned into gardens. In the antiquity, they were rather cult, and in the modern way of life they were mainly practical in their direction (Dobreva 2016). People living in densely populated regions use every free space, including the land.

Roof landscaping has two main types - extensive and intensive. However, they are not strictly defined and there are many intermediate solutions such as semi-intensive and semi-extensive ones etc. (Evstatiev 2012, Sustainable Eastside project 2004, Wark 2003, VEDAG GmbH 2007).

Intensive roof gardening uses flat roofs, it is rich and is provided for walking and recreation. The soil layer is between 20 and $60 \mathrm{~cm}$ thick. A major disadvantage is the higher load on the roof structure, which should be anticipated at the design level of the building. Such roof gardens require system maintenance including watering, mowing, cutting, etc. In the case of roofs of an intensive type, the standard layers are: vapor insulation, waterproofing, protective layer, drainage layer, root insulation, soil substrate and plant layer (Evstatiev 2012).

In extensive landscaping, roof gardens can be extremely simple in the form of roofing boards with low bushes and tree plants, wild herbs and grasses (one-, twoand perennials). In these cases, dry and resistant to periodic over-wetting low plants, which have the ability to regenerate and do not require special care, are used (Evstatiev 2012). The soil layer is less thick than intensive roofing. The load on the construction of the building is not so great that it allows such kind of gardens to be built at any one time. For this type of landscaping, sustainable and unpretentious plants are used. These are predominantly different types of drought-resistant species of succulent plants, sedums, mosses and grasses and flowers. The choice of just such plants is made because they are resistant to drought and freezing of the soil, they have a very shallow and horizontal root system and need a poor soil layer with a depth of 7-10 cm. At the same time they form a beautiful color carpet.

In the extensive landscaping the layers are: steam insulation, heat insulation, waterproofing, drainage layer, root insulation, soil substrate and plant layer. Due to the comparatively small mass of the extensive configurations, there are virtually no restrictions on the material used on the roof slab (Evstatiev 2012).

In the case of intensive roofs, there are virtually no restrictions on the type of plants, which can be limited only by the thickness of the soil substrate, the local climate and the planned budget (Evstatiev 2012, Sustainable Eastside project 2004, Wark 2003, VEDAG GmbH 2007). Airborne dust is found to drop by $42 \%$ below the trees and 


\section{INTERNATIONAL SYMPOSIUM "THE ENVIRONMENT AND THE INDUSTRY", SIMI 2018, PROCEEDINGS BOOK}

this is observed throughout the growing season (that is, when the trees have leaves) compared to places where there are no trees and prevailing open areas (Koleva 2011, Doncheva-Boneva 1987). During the autumn-winter period, there was a significant difference between tree vegetation sites and open areas, although there was a certain decline in vegetation. In the areas where there are tree species, the dust content is $37.5 \%$ less than in the open areas where there are no trees and shrubs (Koleva 2011). Even during the period when the bushes and trees are without leaf cover, they are able to reduce the dust content twice. Not all plant species have the same ability to purify air from dust. Dust-retaining properties depend on several factors, such as the area of the plant, the construction of the leaves and their surface. Rough and sticky leaves hold more dust, and this is true for the leaves covered with hairs.

Table 1. Data from measurements in Sofia, Bulgaria (Borisova garden and nearboulevards) (Koleva 2011)

\begin{tabular}{c|c}
\hline Plant type & Quantity of retained dust, $\mathrm{g} / \mathrm{m}^{2} / 24 \mathrm{~h}$ \\
\hline summer oak & 3.25 \\
mountain ash & 3.25 \\
small poplar & 2.80 \\
birch & 1.9 \\
\hline
\end{tabular}

Measurements have been made in other parts of the country, which show that elm and beech retain 6 and 5 times respectively more dust than the balsamic poplar and the birch - 2.5 times as much as the aspen. Very efficient dust extractors are the odorous willow, the French grapes, the chalice and the bird's grapes. Coniferous species are not very effective in dealing with dust pollution and their efficiency is 30 times less than that of broad-leaved species (Koleva 2011). Green vegetation has the property not only of retaining dust, it has the ability to purify the air from toxic gases such as sulphur, nitrogen and carbon oxides. This process takes place as the harmful substances are trapped and neutralized in the tissues of the plants. Different plant species have different gas accumulation properties. To what extent will the air be purified and the levels of pollution will be reduced depends on several factors plant species, degree and concentration of the pollutant, size of the green areas. Table 2 lists some basic types with high gas absorption capacity.

Table 2. Data from studies on the sulphur dioxide uptake capacity in Sofia's green areas (Koleva 2011)

\begin{tabular}{c|c}
\hline Plant type & Amount of pooled and accumulated sulphur as a result of sulphur dioxide \\
& taken up by air \\
\hline small-linden lime & $7.8(\mathrm{~g} / \mathrm{kg}$ dry leaf matter) \\
mountain ash & $6.45(\mathrm{~g} / \mathrm{kg}$ dry leaf matter $)$ \\
summer oak & $5.75(\mathrm{~g} / \mathrm{kg}$ dry leaf matter) \\
birch & $5.75(\mathrm{~g} / \mathrm{kg}$ dry leaf matter $)$ \\
\hline
\end{tabular}




\section{INTERNATIONAL SYMPOSIUM "THE ENVIRONMENT AND THE INDUSTRY", SIMI 2018, PROCEEDINGS BOOK}

These data are indicative for the abilities of these species to purify the air. Data from studies on the ability of tree and shrub plant species to retain sulphur, which are made in other countries and are listed in Table 3 (Koleva 2011).

For urban landscaping, it is advisable to use species that are highly resistant to air contamination. For areas with high levels of pollution as Sofia, suitable species are: white dogwood, usually bird's grapes, narrow-leaved willow, sixth, sumac, tattooed claw. In case of moderate or reduced air contamination suitable species are white willow, white acacia, summer oak, sophora, white mulberry, mosquito, mountain ash, philatelus, and calinolist subduct. It is not recommended to use small-linden lime, caraway wood, and common lilac.

Table 3. Data from studies conducted in areas with low pollution for the sulphur dioxide uptake capacity of green areas (Koleva 2011)

\begin{tabular}{cc}
\hline Plant type & $\begin{array}{c}\text { Amount of pooled and accumulated sulphur as a } \\
\text { result of sulphur dioxide taken up from the air }\end{array}$ \\
\hline $\begin{array}{c}\text { white dogwood usually poultry grapes, } \\
\text { black currants, tartar claw, narrow-leaved } \\
\text { willow, white willow }\end{array}$ & $4.16-7.36 \mathrm{~g} / \mathrm{kg}$ dry matter \\
$\begin{array}{c}\text { a simple birch, a simple lilac, a shiny } \\
\text { cotoneaster }\end{array}$ & $1.24-1.92 \mathrm{~g} / \mathrm{kg}$ dry matter \\
$\begin{array}{c}\text { a canine-lipped sub-plant and some apple } \\
\text { species }\end{array}$ & $2.10-3.84 \mathrm{~g} / \mathrm{kg}$ dry matter \\
\hline
\end{tabular}

Table 4. Data from studies conducted in areas with intensive pollution for the sulphur dioxide uptake capacity of green areas (Koleva 2011)

\begin{tabular}{c|c}
\hline Plant type & $\begin{array}{c}\text { Amount of pooled and accumulated sulphur as a } \\
\text { result of sulphur dioxide taken up from the air }\end{array}$ \\
\hline $\begin{array}{c}\text { white dogwood usually poultry grapes, } \\
\text { black currants, tartar claw, narrow-leaved } \\
\text { willow, white willow }\end{array}$ & $4.16-7.36 \mathrm{~g} / \mathrm{kg}$ dry matter \\
$\begin{array}{c}\text { a simple birch, a simple lilac, a shiny } \\
\text { cotoneaster }\end{array}$ & $1.24-1.92 \mathrm{~g} / \mathrm{kg}$ dry matter \\
$\begin{array}{c}\text { a canine-lipped sub-plant and some apple } \\
\text { species }\end{array}$ & $2.10-3.84 \mathrm{~g} / \mathrm{kg}$ dry matter \\
\hline
\end{tabular}

In areas where pollution is not high it is recommended to use plant species that are highly gas-absorbing. Here you can use the above-mentioned gas-resistant species and some other plant species such as black currant and some apples. Succulent plants can also be used that have the ability to accumulate sulphur, but they still have to show a high enough gas resistance. Appropriate for this purpose are silver spruce, shiny bird's grapes, white acacia, mountain ash, cornflakes. In areas with low levels of pollution, some plant species that are not suitable for areas with high levels of contamination may also be used. These are species that have increased sensitivity to harmful gases (in fact, they can be used as an indicator of the air condition in the 


\section{INTERNATIONAL SYMPOSIUM "THE ENVIRONMENT AND THE INDUSTRY", SIMI 2018, PROCEEDINGS BOOK}

area). Such are the lime-grass, the tree-beetle, the common lilac, the birch, the Turkstone oak, the thistle.

The roof gardens presented in Figures 1,2,3,4, and 5 are examples of contemporary solutions to the problems of air purification and increasing the amount of green areas in cities. Still such types of gardens are mainly built on roofs of hotels and public buildings, and residential buildings are rare. They are also a wonderful ecological and aesthetic solution.

The idea of building roof gardens is applicable worldwide. We will also hope to see more and more of these beautiful, spectacular and environmentally-friendly solutions for industrial, administrative, public and private buildings, which are still the privilege of the rich. Roof landscaping can be built even in areas with less favorable climatic conditions (http://www.highviewart.com/eko/pokrivnite-gradiniot-ptichi-pogled-481.html). Figures $8,9,10$ and 11 are examples of beautiful gardens in places with harsh climatic conditions than those in moderate latitudes.

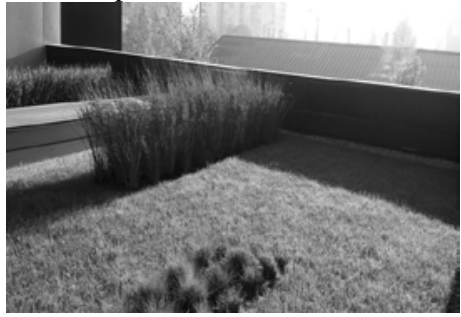

Figure 1. Roof landscaping on the terrace of DSK Bank building in Lyulin - Sofia, Bulgaria

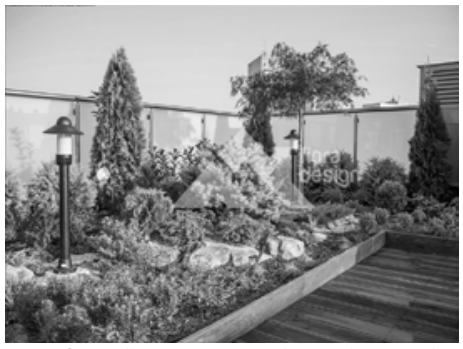

Figure 3. Sofia, Bulgaria - intensive roof garden: $120 \mathrm{~m}^{2}$

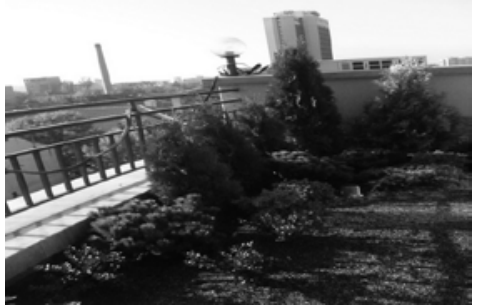

Figure 2. Roof landscaping of a building in Sofia, Bulgaria - greening company Green project

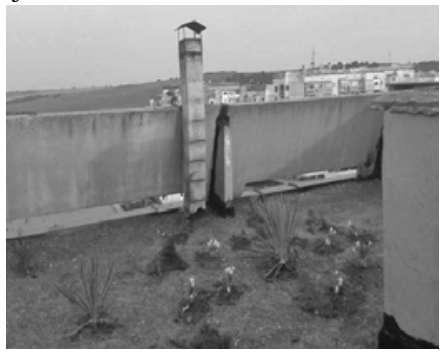

Figure 4. Roof in Ruse, Bulgaria 


\section{INTERNATIONAL SYMPOSIUM "THE ENVIRONMENT AND THE INDUSTRY", SIMI 2018, PROCEEDINGS BOOK}

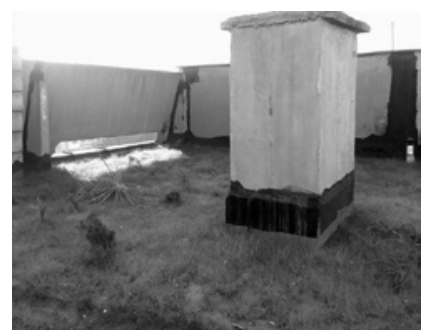

Figure 5. Roof in Ruse, Bulgaria

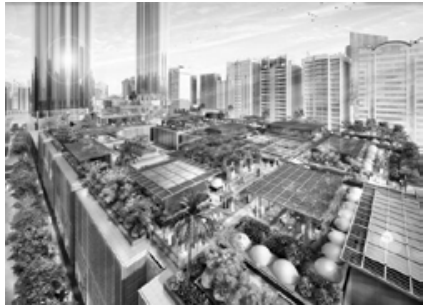

Figure 6. Foster \& Partners is also behind another green project in the Middle East - a solar-powered international airport in Kuwait

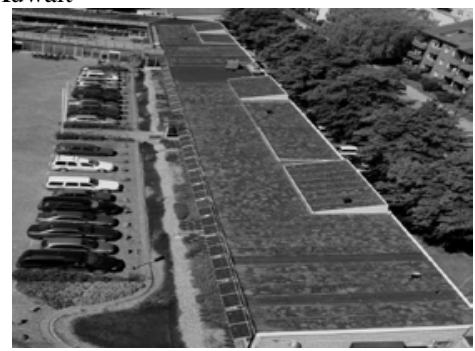

Figure 8. Malmo, Sweden

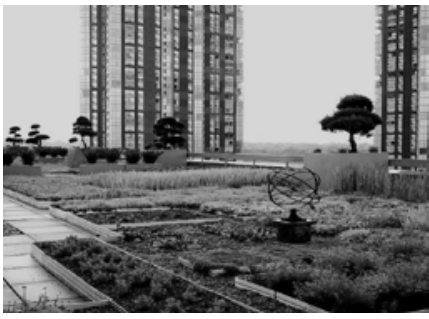

Figure 7. Toronto, Canada

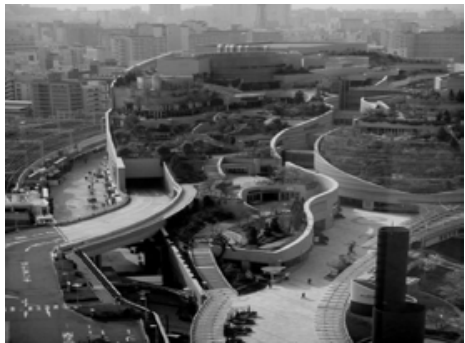

Figure 9. Osaka, Japan

\section{Materials and Methods}

Protection Partnership Department, the Environmental Protection Agency Environmental Protection Agency (EEA), provides data that $93 \mathrm{~m}^{2}$ of green roof space can reduce dust emissions in the air by $18.14 \mathrm{~kg} /$ year, while producing oxygen and removing carbon dioxide $\left(\mathrm{CO}_{2}\right)$ from the atmosphere.

Using the data released by the US Environmental Agency, a study has been carried out on the possibility of reducing dust emissions from the territory of the industrial zone of the city of Ruse, located on the bank of the river Danube. With the help of the software product PLUME approved at national level for Bulgaria, a computer 


\section{INTERNATIONAL SYMPOSIUM "THE ENVIRONMENT AND THE INDUSTRY", SIMI 2018, PROCEEDINGS BOOK}

simulation was carried out to determine the mean annual concentration of dust from industrial sources on the territory of Industrial zone of city of Ruse, Bulgaria without the presence of green roof spaces and after the realization of the green roof of two of the production buildings and an administrative building in the area.

The total area of the green roof areas for the area under consideration is 6,198 square meters, with projections that roofing systems contribute to reducing dust emissions from industrial sources by $1,222 \mathrm{~kg} /$ year.

Current situation in the region of Industrial zone of Ruse, Bulgaria is shown in the figure10: PLUME software works with a coordinate grid $(\mathrm{x}, \mathrm{y})$, with the studied area of the air pool having parameters $16000 \times 16000 \mathrm{~m}$ or 32 steps $* 500 \mathrm{~m}$. The model is made with the type of underlying surface "urban area" as the industrial zone is located in the regulation boundaries of the town of Ruse.

The wind rose and the average annual temperature for the city of Ruse is from the Climate Guide of the Republic of Bulgaria, volume 3: Air temperature, soil temperature, frost and volume 4: Wind. They are used as inputs in terms of meteorological conditions for PLUME software.

Figure 10 presents the isolines of the average annual dust concentrations from the Industrial Zone of Ruse. The estimated maximum dust concentration in the area under investigation is $1.79 \mu \mathrm{g} / \mathrm{m}^{3}$, spreading in the Northeast direction. This value represents $4.5 \%$ of the annual human health protection standard $\left(40 \mu \mathrm{g} / \mathrm{m}^{3}\right)$.

Simulation after the realization of green roof spaces in the region of Industrial zone of city of Ruse, Bulgaria is also made and presented.

In figure 11 the isolines of the average annual dust concentrations are presented. The estimated maximum annual average concentration of dust in the area under investigation is $0.79 \mu \mathrm{g} / \mathrm{m}^{3}$, propagating in the Northeast direction. The value represents $2 \%$ of the annual human health protection standard $\left(40 \mu \mathrm{g} / \mathrm{m}^{3}\right)$. This means that the maximum annual average concentration of dust after the building of green roofs is more than two times less than the one without green roofs.

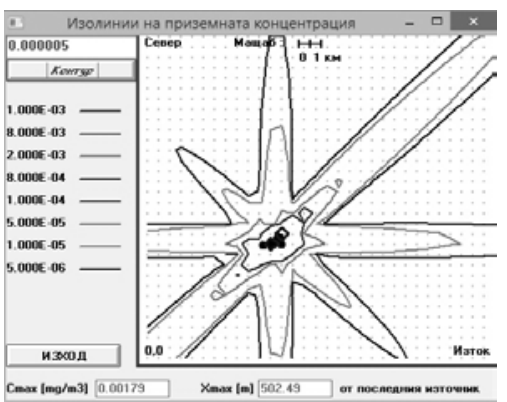

Figure 10. Average annual concentrations of dust from the territory of the Industrial zone Ruse, Bulgaria

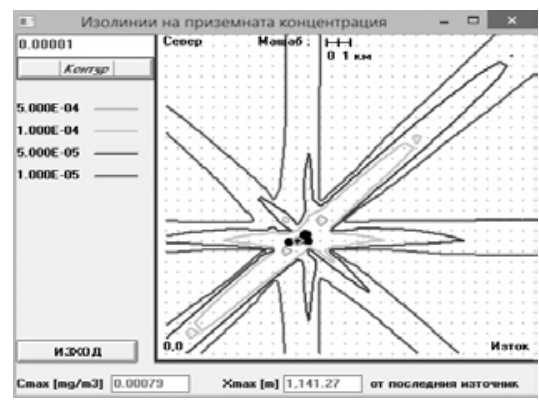

Figure 11. Average annual concentrations of dust from the territory of the Industrial zone Ruse, Bulgaria after green roofs building 


\section{INTERNATIONAL SYMPOSIUM "THE ENVIRONMENT AND THE INDUSTRY", SIMI 2018, PROCEEDINGS BOOK}

\section{Conclusions}

The construction of mini-ecosystems in the urban environment is a guideline in architecture, design and ecology, which is related to the improvement of the urban environment. It is gaining increasing popularity and is growing ever more intensely. It is increasingly involved in the realization of projects related to building more green areas in urban environments and the use of free urban spaces to increase greenery. Serious investments are needed for research and studies on how roof gardening has an impact on city air purification. There is still insufficient reliable information gathered to testify these facts. It is obvious that research, experimentation and work in this field are needed. It is necessary to collect more data as ours from this paper on the air condition, the levels of pollution before and after the construction of the gardens. Only then it will be ascertained to what extent roofing landscaping deals with the problem and how its efficiency can be improved. More time is needed to gather information on the most appropriate type of roofing that will best deal with the specific air contamination in a given area. Roof gardens are part of future technologies that will lead to a better environment, cleaner air, and people's health improvement. They have to become a priority and have to be promoted at national level by the state.

\section{References}

Dobreva, I 2016, 'Dragostanova AB of sustainable design', Ed. New Bulgarian University.

Doncheva - Boneva, M 1987, 'Protective functions of woody vegetation against dust and gas pollution', dissertation thesis, Sofia University, Bulgaria.

Evstatiev, BI 2012, 'Application of modeling and simulation of physical processes in sizing and operation of buildings with green roofs', monograph Ruse University "Angel Kanchev", Ruse.

Koleva, P 2011, 'Geometric plant compositions', Matcom. Sofia, pp. 318.

Sustainable East side project, 2004, 'Livingroofs.org. Green roofs. Benefits and coast implications', London.

VEDAG GmbH, 2007, 'Green roof gardens; creating a natural environment'.

Wark, C \& Wark, W 2003, 'Green Roofs Specifications and Standards: Establishing emerging technology', The Construction Specifier, vol. 65, no. 8, pp. 12-23.

http:/www.blog.imotidoverie.bg/2015/11/raiska-gradina-na-pokriva/.

[02 July 2018]. In Bulgarian.

http://citybuild.bg/news/krasivi-zeleni-sgradi-blizkiia/21662. [02 July 2018]. In Bulgarian.

http://fiora.eu/. [02 July 2018]. In Bulgarian.

https://greenprobg.com/2016/12/09. [02 July 2018]. In Bulgarian.

http://www.highviewart.com/eko/pokrivnite-gradini-ot-ptichi-pogled-481.html.

[02 July 2018]. In Bulgarian.

http://unigarden-bg.com/ozeleniavane/pokrivno/. [02 July 2018]. In Bulgarian. 